\title{
MANUSKRIP DAN PRIBUMISASI FIKIH DI LOMBOK (Studi atas Peran Manuskrip terhadap Persebaran Fikih Lokal)
}

\author{
Lalu Muhammad Ariadi \\ Institut Agama Islan Hanzanuadi (lAlH) Pancor \\ Jalan TGKH. Zaimuddin Abdul Madjid Pancor Lombok Timur, NTB \\ Email: Laluariadiàmail.com
}

\begin{abstract}
Abstrak
Sebagai agama yang mensinkronkan teks dengan perkembangan sosio-kultural, Islam menjadi agama yang tidak terpaku kepada pemaknaan ajaran-ajaran agama dalam sebuah teks. Selain ditandai dengan pemahaman keagamaan yang dinamis, sinkronisasi ini juga tercermin dari maraknya penulisan teks keagamaan dalam dunia Islam, sehingga Islam menyebar ke berbagai wilayah dunia sebagai agama yang konstruktif dan damai. Di Indonesia, perkembangan ini tercermin pada pola kulturisasi isi naskah-naskah kuno secara sosio-kultural. Hal ini di antaranya bisa dilihat dari cara orang-orang Sasak di Lombok mempelajari dan menghayati ajaranajaran fikih dalam naskah-naskah kuno, baik itu yang berbahasa Jawi, maupun Kawi. Selain merefleksikan akulturasi antara aksara Jawi dan Kawi dengan kebudayaankebudayaan lokal yang menyebar di antara berbagai pulau di Indonesia, kulturisasi literatur-literatur tersebut menandakan dinamisnya pemahaman orang-orang Islam di Indonesia. Baik dari sisi fikih, tasawuf, maupun dari sisi kebudayaan. Artinya bahwa pemahaman suku-suku bangsa yang menganut Islam di Indonesia tentang fikih tidak seragam.
\end{abstract}

Kata kunci: pribumisasi Islam, fikih, Jawi, Sasak, Lombok

\begin{abstract}
As a religion that synchronizes text with socio-cultural developments, Islam is the religion that is not glued to the textual interpretation of religious teachings. In addition to the dynamic religious understanding, this synchronization is also reflected in the rise of the writing of religious texts in the Islamic world, so that Islam is spread to various parts of the world as a constructive and peaceful religion. In Indonesia, this development is reflected in the pattern of acculturation in sociocultural aspects of the ancient manuscripts. It can be seen in the way of Sasak people in Lombok to learn and live the teachings of $f i q h$ in ancient texts, whether they are the Jawi and Kawi languages. In addition to reflecting the acculturation between Jawi and Kawi scripts with local cultures that spread among the various islands in Indonesia, acculturation of the literature indicates dynamic understanding of Muslims in Indonesia, whether in terms of jurisprudence, Sufism, and in terms of culture. Therefore, it can be said that in understanding Islamic jurisprudence, local people in Indonesia who embraced Islam is not uniform.
\end{abstract}

Keywords: acculturation of Islam, fiqh, Jawi, Sasak, Lombok 


\section{A. Pendahuluan}

Salah satu perkembangan sastra yang secara simultan mempengaruhi perjalanan kebudayaan-kebudayaan Nusantara sejak era pra sejarah adalah "kesusastraan dalam manuskrip". Sastra ini melalui berbagai macam jalan, termasuk jalan perdagangan antara pulaupulau di Nusantara memunculkan pola kebahasaan yang unik pada berbagai suku yang tinggal di pulau-pulau tersebut. Pola tersebut diantaranya terkait dengan pola pikir kultural, ungkapan sehari-hari, cara menceritakan kisah nenek moyang, dialek kebahasaan, dan penggunaan berbagai macam istilah kebahasaan itu sendiri. Contoh dari hal ini dapat dilihat pada cara orang Melayu Loloan di Bali, orang Melayu Papua, dan orang Sasak di Lombok mengungkapkan sesuatu. Orang Melayu Loloan yang berprofesi sebagai pedagang memiliki kebiasaan untuk mengatakan "mari sini, ada barang elokelok" kepada orang-orang yang lewat. Orang Melayu Papua merubah imbuhan me menjadi ma saat berbicara, seperti kata melihat menjadi maliat, dan atau melotot menjadi malotot. Dan orang Sasak di Lombok acapkali mengatakan "sila' dateng lek acare berpisah ...." saat mengedarkan undangan acara syukuran bagi orang yang akan berangkat menunaikan ibadah haji. '

Selain berperan terhadap akulturasi antara kebudayan-kebudayaan, kesusastraan dalam manuskrip juga menjadi media yang sangat penting dari penyebaran agama-agama di Nusantara, baik itu agama Budha, Hindu, maupun Islam. Pada pengajaran ajaran ajaran Budha dan Hindu misalnya, manuskripmanuskrip yang ditulis dengan aksara Sanksekerta dan Kawi menjadi dasar dari kemunculan kedua agama ini sebagai agama yang mayoritas pada era pra kedatangan Islam, sekaligus sebagai pilar dari kemunculan peradaban Budha dan Hindu di Nusantara.

Ketika Islam datang, pola ini ini digunakan oleh para muballigh Islam untuk menanamkan ajaran-ajaran Islam secara sosio kultural. Sehingga tidak mengherankan, apabila aksara Kawi masih digunakan dalam penulisan ajaranajaran Islam dalam naskah, dan juga terkait secara erat dengan timbulnya perpaduan aksara Arab dan Melayu pada penulisan naskah-naskah keagamaan di Nusantara. Aksara ini, oleh para penggiat dakwah Islam dan penganut agama Islam pada masa lalu dikenal dengan aksara Jawi.

Secara historis-antropologis, aksara Jawi yang banyak menyebar di Nusantara berdifusi dengan bahasa setempat dan membentuk dialek yang unik di sepanjang kepulauan Nusantara. Dialek ini, meski sangat beragam, namun masik berakar pada dialek orang Melayu itu sendiri. Menurut Collins, berpuluh-puluh dialek Melayu menyebar di Nusantara, yaitu dari pesisir barat Pulau Sumatera hingga pesisir pulau Papua, dan dari wilayah negeri Thai hingga pulau Cocos Keeling di Samudera Selatan. Hadirnya enam puluh dialek daerah yang tergolong dalam jaringan bahasa Melayu menjadi bukti keunggulan penutur Melayu sebagai perintis budaya, niaga, dan teknologi di Nusantara. Dialek-dialek ini datang melalui arus imigran yang datang dari Sumatera. Dan juga melalui kontak perdagangan yang kuat pada masa kerajaan Sriwijaya. ${ }^{2}$

Bersamaan dengan kedatangan dialek Melayu, berbagai tradisi keagamaan yang kental dengan nuansa keislaman, khususnya fikih, beserta naskah-naskah yang beraksara Arab Melayu atau Jawi datang ke suku-suku yang mendapat pengaruh Melayu tersebut. Di Gorontalo, aksara Arab Melayu membentuk rangkaian hubungan kebahasaan yang terkait erat antara bahasa Gorontalo dengan bahasa Melayu, seperti dalam Naskah Me'eraji Li Nabi Muhammad. Begitupun dengan daerah Bima, dimana aksara Arab Melayu dalam naskah Syair Kerajaan Bima melahirkan tradisi orang-orang Bima yang kental 
dengan Islam, seperti tradisi pemakaian Rimbu bagi para wanita di Bima. ${ }^{3}$ Lalu, diantara orang Sasak di Lombok, tradisitradisi Melayu terangkai erat dengan pembelajaran dan penulisan naskahnaskah Arab Melayu pada masyarakat pedesaan. Naskah-naskah berbahasa Jawi seperti, a/-Tuhfah a/-Mursalah ila Ruh a/Nabi, Bayān al-Taşđq, Insān Kamùl, Fath al-Rahmōn, Ma'rifat al-Jabbar, Tarckat Imāom Abū Hasan, Samarqandĭ, Qishash a/-Anbiya, dan Sayr al-Salikin dipahami dan dipelajari sebelum ditulis ulang melalui tradisi Bchikayat oleh orang-orang Sasak. Semua naskah ini melahirkan perpaduan ajaran-ajaran tarekat dan fikih diantara orang-orang Sasak di Lombok. Selain itu, pada naskah-naskah beraksara Kawi dan Sasaka seperti Serat Rengganis, Wayang Menak, Jati Suara, Jati Rasa, Manusia Jati, dan naskah-naskah lainnya, tradisi Bewacan membuat alur penceritaan dalam naskah seperti pola mengisahkan kehidupan dalam Hikayat Orang Melayu. ${ }^{4}$ Atas dasar hubungan ini, khususnya yang terkait dengan perkembangan fikih lokal berbasis naskah di Lombok, maka deskripsi dan analisis mendalam terhadap tradisi pernaskahan yang terhubung dengan pribumisasi dan kulturisasi ajaran-ajaran fikih tersebut menjadi sebuah kemestian intelektual, dan juga kebudayaan.

\section{B. Sejarah Perkembangan Naskah- Naskah Keagamaan di Lombok}

Secara historis, kedatangan dan perkembangan berbagai naskah-naskah keagamaan di Lombok sangat terkait dengan perkembangan agama-agama di Nusantara, yaitu agama-agama pra Islam seperti agama Budha dan Hindu, dan agama Islam itu sendiri. Sehingga, apabila dipetakan, naskah-naskah ini terbagi kepada naskah-naskah keagamaan sebelum datangnya Islam dan naskahnaskah setelah kedatangan dan penyebaran Islam. Naskah keagamaan pra menyebarnya Islam diantaranya adalah Negara Kertagama yang ditulis Empu Prapanca pada masa kerajaan Majapahit. Sedangkan naskah keagamaan pasca penyebaran Islam adalah al-Twhfah a/-Mursalah ila Ruhh al-Nabi yang ditulis oleh al-Burhanpuri. ${ }^{5}$

Pada masa lalu, peran penulisan ajaran-ajaran keagamaan dalam berbagai media, baik itu di Batu, daun lontar yang dikeringkan, dan berbagai kulit hewan yang disamak menjadi salah satu faktor penentu keberhasilan penyebaran dan pengajaran ajaran-ajaran yang dibawa oleh suatu agama. Melalui penulisan ini, ajaran-ajaran keagamaan dijaga dan diwariskan secara turun temurun dari satu generasi ke generasi selanjutnya. Oleh mereka yang menyimpan naskah-naskah tersebut dan masyarakat secara umum di Nusantara, kumpulan tulisan-tulisan itu dikenal dengan Lontar atau Jontal. ${ }^{6}$

Sebagai salah satu faktor penentu keberhasilan penyebaran ajaran-ajaran keagamaan, penulisan naskah-naskah keagamaan berperan penting terhadap kesuksesan akulturasi ajaran-ajaran sebuah agama dengan berbagai kebudayaan lokal di yang ada di sekitar Nusantara. Pada masa penyebaran ajaranajaran Islam di Nusantara misalnya, penulisan kembali naskah-naskah yang dibawa dari wilayah Gujarat di India dan Hadramaut di Arab dan telah diadaptasikan dengan kebudayaan setempat melahirkan bentuk praktek keberislaman yang ramah dan membangun di Nusantara. Hal ini diantaranya bisa dilihat pada perubahan naskah-naskah pewayangan di Jawa dan Lombok. Naskah-naskah pewayangan di Jawa yang semula berisi ajaran-ajaran Hindu bermetamorfosa menjadi pengisahan pewayangan berbasis nilainilai keislaman, seperti nilai-nilai ketauhidan dalam Sekaten dan persamaan derajat manusia. Begitupun dengan naskah-naskah pewayangan di Lombok yang memberikan nama-nama tokohnya dengan nama Islam, seperti Amir Hamzah. Melalui adaptasi ini, makna- 
makna universal dalam ajaran-ajaran Islam, termasuk yang terkait dengan fikih di ajarkan, dan sekaligus dikulturisasikan. $^{7}$

Setelah kedatangan Islam di Nusantara, naska-naskah keagamaan secara umum ditulis dengan aksara Kawi dan Jawi. Aksara Kawi adalah perpaduan antara bahasa Sansekerta dengan Jawa. Sedangkan aksara Jawi merupakan perpaduan bahasa Arab dengan Melayu. Dalam hal ini, selain merefleksikan akulturasi antara dua bahasa, aksara Kawi dan Jawi masing masing menjadi penanda bentuk kebudayaan yang dominan di Nusantara, yaitu kebudayaan orang Jawa dan orang Melayu. ${ }^{8}$

Sebagai refleksi dari kebudayaan sebuah suku bangsa, aksara kawi dan jawi pada akhirnya tidak sekedar merangkum ajaran-ajaran Islam yang dianut oleh suku bangsa tersebut. Namun lebih dari itu, aksara ini mengawinkan tradisi-tradisi dalam Islam dengan tradisitradisi yang berlaku dalam masyarakat itu sendiri. Ini misalnya dapat dilihat pada Hikayat Hasanuddin dan tradisi orangorang di Banten meyakini Mekah sebagai pusat kosmis dan supranaturalitas, seperti yang berlaku pada keyakinan orang Jawa akan kekuatan gunung."

Berbeda dengan apa yang terjadi di Banten dan wilayah-wilayah lain di Jawa yang meyakini Mekah sebagai pusat kosmis, orang-orang Sasak di Lombok lebih meyakini Mekah dengan Ka'bah di dalamnya sebagai bagian dari cara memahami makna-makna dalam ibadah haji, -sebagai salah satu ibadah inti dalam Islam-, sekaligus sebagai simbol kebudayaan mereka. Diantara orang Sasak, semua ini termanifestasi pada ritual "Behajï" ${ }^{10}$

Suku Sasak yang dalam kehidupan sehari-hari memiliki ritual-ritual berbasis pengembangan dan pengajaran ajaranajaran Islam dalam fikih, seperti Behikayat, Beteteh untuk pelaku zina, dan Behaji merupakan nama suku yang mendiami Pulau Lombok." Pulau
Lombok adalah salah satu pulau utama di Propinsi Nusa Tenggara Barat yang sejak masa pra sejarah menjadi tempat singgah berbagai suku bangsa, baik itu suku bangsa Austronesia, Jawa, Sunda, maupun Melayu. Propinsi ini terletak di wilayah Tenggara Indonesia yang terdiri dari dua buah pulau utama, yaitu Pulau Sumbawa dan Lombok dengan batas wilayah sebelah Utara: Laut Jawa dan Laut Flores; sebelah Selatan: Samudra Indonesia; sebelah Timur: Selat Sape/Propinsi NTT; sebelah Barat: Selat Lombok/Propinsi Bali. ${ }^{12}$ Meskipun propinsi ini diapit oleh Propinsi Bali yang mayoritas penduduknya beragama Hindu, dan Propinsi Nusa Tenggara Timur yang mayoritas penduduknya beragama Kristen, namun mayoritas penduduk NTB merupakan penganut agama Islam, dengan presentase $94 \%$ penganut agama Islam; 2,6\% Hindu; 0,9\% Kristen; 0,6\% Budha. ${ }^{13}$

Dalam

Negarakertagama disebutkan bahwa pada abad ke-14 terdapat dua pulau di antara wilayah Hindu Bali dan wilayah Timur, yaitu Pulau Samawa (Sumbawa) dan Lombok. Di Pulau Samawa terdapat Bima, Dompu, Taliwang, Seran, dan Utan Kedali. Sedangkan di Pulau Lombok terdapat Lombok Mirah di wilayah Lombok Barat dan Sasak Adi di wilayah Lombok Timur. $^{14}$ Penduduk pertama Pulau Lombok berasal dari suku bangsa dan ras Mongoloid yang berasal dari Asia bagian tenggara. ${ }^{15} \mathrm{Hal}$ ini terlihat dari penemuan benda-benda arkeologis di Gunung Piring Desa Truwai Kecamatan Pujut, Lombok Selatan. Benda-benda purbakala yang ditemukan di desa ini berupa periuk utuh, kereweng, kerangka manusia, arca Budha Awalokiteswara, nekara, dan batu nisan yang bertuliskan huruf Cina dan Arab. Berdasarkan temuan ini, disimpulkan bahwa sejak akhir zaman perunggu, Nusa Tenggara Barat khususnya Lombok telah dihuni oleh sekelompok manusia yang memiliki kebudayaan yang sama dengan manusia yang mendiami Gua Tabon 
Vietnam Selatan, penduduk yang mendiami Pulau Pallawan-Filipina, penduduk di Gilimanuk Bali, dan penduduk di Malielo-Sumba. ${ }^{16}$ Meski penemuan benda-benda arkeologis di Gunung Piring memberikan petunjuk mengenai penduduk pertama Pulau Lombok, namun sampai saat ini petunjuk pasti tentang penduduk asli Pulau Lombok belum terungkap.

Kebudayaan orang Sasak yang berkembang di Lombok adalah manifestasi dari dua hal, yaitu kebudayaan yang berkembang dari pemahaman kebudayaan akan hubungan manusia, makhluk hidup, dan alam, dan juga metamorfosa makna-makna hidup yang dikandung naskah-naskah sosial keagamaan yang digunakan oleh orang Sasak pada wilayah kultural, khususnya Islam pada saat ini. Kedua hal ini terinterpretasi secara sosio kultural di Lombok menjadi tradisi pernaskahan dengan berbagai ritual dan tradisi lain yang mengiringinya, yaitu tradisi Behikayat yang merupakan seni tradisi bercerita orang Sasak dan sekaligus cara orang Sasak membaca naskah-naskah Arab Melayu yang mereka miliki. Selain itu, tradisi Bewacan yang merupakan seni membaca naskah-naskah berbahasa Kawi dan Sasaka menjadi sisi lain tradisi yang mengiringi tradisi pernasakahan di Lombok. Kedua tradisi ini membuat tradisi pernaskahan di Lombok menjadi tradisi yang hidup, bukan sekedar tradisi yang berbasis teks-teks dalam naskahnaskah kuno. ${ }^{17}$

Terkait dengan hal ini, apabila dipetakan, naskah-naskah ini terbagi kepada naskah-naskah keagamaan sebelum datangnya Islam dan naskahnaskah setelah kedatangan dan penyebaran Islam. Naskah keagamaan pra menyebarnya Islam kebanyakan menggunakan aksara Kawi dan Sasaka. Naskah-naskah ini memiliki enam tembang yang populer yaitu tembang Durma, Sinom, Smaranda, Pangkur, Dangdang, dan Maskumambang.
Sedangkan tembang kurang populer diantaranyada adalah tembang Kinanti, Girisa, dan Kasmaran. Banyak bentuk penyusunan bait-bait dalam tembangtembang ini mengikuti pola alur penyusunan bait-bait puisi dan prosa sastra Melayu. Contohnya bisa dilihat pada tembang Dangdang bait-bait dari naskah Cilinaya berikut ini, yaitu pada bait ke-14:

Banjur dateng angin topan gelis, si kesukaq Allah si kuasa

(Tiba-tiba berhembus angin puting beliung, dengan Takdir Allah Yang Maha Kuasa)

Bijan Datu Daha nane, takelepan ya batur, siq anginna no nengka glis

(Putri Raja Daha kemudian diterbangkan ke atas oleh angin dengan begitu cepat)

Kaget Datu nyreminang, pada momot ya banjur

(Raja terperanjat menyaksikan, tertegun tak mampu berbuat sesuatu)

Datu bini, Datu Lanang nyengoq bija

(Permaisuri dan Raja memandang kepergian putrinya)

Ngawang ngawang Neneq bini

(Melayang-melayang sang putri)

Datu nongaq langit dowang.

(Raja hanya memandang langit saja)

Selain itu, pada tembang Sinom bait ke-14 naskah Rengganis dikatakan:

Goyo Taruna ndeqna gila, Siq toaq bajerik tarik

(Jangankan pemuda takkan tergilagila, kaum tua pun kembali)

Kyai pada badoa, Guru Tuan gurik tahlil

(Para Kiyai merapal doa, Guru Tuan membaca tahlil)

Sangkaq lueq Guru Kyai lupaq tarekat Tuan Guru

(Karena banyak Guru Kiyai lupa ajaran Tuan Guru) 
Si angena kambelisan, pada mele bawa diriq

(Karena iman tergoncang, ingin menonjolkan diri sendiri)

Mupakat mele pada engkah sembahyang.

(Bermufakat tinggalkan sembahyang) ${ }^{18}$

Kedua bait tersebut bersama baitbait selanjutnya dibaca dengan nyanyi panjang dalam ritual menembang yang dikenal dengan Bewacan. Nyanyi panjang ini dibaca dan dinikmati bersama-sama. Nyanyi ini juga acapkali diiringi suara Pereret yang ditiup seperti orang yang bernapas dan tanpa jeda yang panjang. ${ }^{19}$

Adapun naskah keagamaan pasca menyebarnya Islam yang diperkirakan mulai ada sejak abad ke-16 menggunakan aksara Kawi, Sasaka, dan Arab Melayu. Pada naskah-naskah beraksara Arab Melayu, pembacaan dengan Behikayat menjadi sebuah ritual yang mesti ada. Seperti pada tradisi Nyanyi Panjang masyarakat Petalangan, Riau, Behikayat ditampilkan pada perayaan-perayaan tertentu. Baik itu seperti pada pesta perkawinan, perayaan anak-anak yang sunatan, dan pada acara Berpisah yang dilaksanakan para calon haji yang akan berangkat ke Mekah. Naskah-naskah yang dibaca pada ritual Behikayat adalah Oamaruzzaman, Hikayat Ali Hanafiah, Hikayat Nabi-Nabi (Qishāsh a/-Anbiyā), Nabi Bercukur, Insān Kamül dan lain sebagainya. $^{20}$ Selain sebagai tradisi bercerita orang-orang Sasak di pedesaan, ritual ini menjadi media yang sangat penting dalam mengajarkan ajaran-ajaran Islam, baik secara sufistik, maupun tidak. Contoh dari bait-bait dalam naskah beraksara arab Melayu ini adalah : "Bemula sesudah kita sembahyang, maka kita hadapkan muka kita kepada Allah, maka kita baca salamnya kepadaNya: Allahumma as-Salamu alaikum ya arwah al-muqaddasati ya qutub ya amin...".
Pada masa penyebaran ajaranajaran Islam di Nusantara, naskah-naskah keagamaan tersebut berperan penting terhadap kesuksesan akulturasi ajaranajaran fikih dalam Islam dengan berbagai kebudayaan lokal, termasuk kebudayaan orang Sasak di Lombok. Naskah-naskah yang banyak bersumber dari sastra Melayu tersebut menjadi penanda penting pengaruh budaya Melayu yang tidak hanya hanya terhenti pada pola dan dialek kebahasaan semata. Namun, lebih dari itu, ini merupakan bukti konkret pengaruh budaya Melayu pada wilayah yang lebih luas, yaitu wilayah keagamaan dan kebudayaan. ${ }^{21}$ Ini terlihat secara jelas pada ritual Behaji, Behikayat, dan filosofi dari tari Shaman di pedesaan orang-orang Sasak.

Ritual "Behaji" pada orang-orang Sasak adalah tradisi yang mengakulturasikan spirit-spirit ketuhanan dan kemanusiaan di dalam ibadah haji dengan dua falsafah dasar kebudayaan orang Sasak, yaitu tradisi kesasakan, dan dengan ajaran-ajaran spiritual dalam falsafah Sa'sa' Lombo'. Sehingga, haji bagi mereka tidak hanya fokus kepada pelaksanaan ibadah haji dalam Islam semata, namun menjadi penggerak perubahan sosial dan kebudayan, sekaligus sebagai dasar etika, kebudayaan, dan keberagamaan orang Sasak. Pemaknaan inilah yang menjadi pembeda pemahaman orang Sasak tentang haji dengan orang Jawa, Betawi, dan Medan yang cenderung menjadikan haji sebagai ritual agama, cita-cita keagamaan dalam hidup, dan simbol sebuah status sosial-keagamaan. Diantara orang Sasak, keyakinan dan kebudayaan tercermin dari naskah-naskah keagamaan yang puncaknya adalah simbol Ka'bah itu sendiri. Naskah-naskah ini diantaranya adalah Ka'bah al-Haqiqah a/Ma'rifah, sebuah kitab yang menjadi salah satu acuan penganut tarekat di Lombok, naskah Sabuk Desa Ketangga yang menceritakan tentang prosesi haji dan pemaknaannya, Insān Kamil dan 
Ma'rifat al-Jabbar yang membicarakan ajaran-ajaran Islam secara lahiriah dan batiniah, termasuk didalamnya mengenai haji dan Ka'bah. Semua naskah ini ditulis dengan aksara Jawi atau Arab Melayu. 2.2

Selain dengan menggunakan aksara Jawi, penjelasan tentang Mekah dan Ka'bah diantara naskah-naskah keagamaan di Lombok juga ditulis dengan aksara Kawi dan Sasaka. Diantara naskah-naskah ini adalah Serat Rengganis yang isinya tentang sosok Rengganis yang mencari makna ketuhanan dengan melakukan napak tilas perjalanan ke Mekah. Lalu ada naskah Indarjaya Sasak yang membahas secara mendalam konsep ketuhanan dan jati diri manusia dalam tasawuf yang tentunya didalamnya ada simbolisasi akan Ka'bah. ${ }^{23}$

Di pulau yang terletak di Propinsi Nusa Tenggara Barat ini, naskah-naskah keagamaan dengan konteks pembicaraan seputar Mekah dan Ka'bah tersebut mempengaruhi pola keberislaman dan aliran kebudayaan orang-orang Sasak. Secara nyata, ini nampak pada sejarah dari masuk dan berkembangnya Islam yang tak pernah luput dari figur haji. Saat Islam datang di Lombok, para muballigh Islam yang mengajarkan Islam diyakini orang-orang Sasak sebagai orang suci yang sudah haji. Mereka adalah Syaikh Nurur Rasyid, Wali Nyatok atau Sayyid Ali, Sunan Prapen, Sunan Pengging, dan Tuan Lebay. ${ }^{24}$

Pada perkembangannya, keyakinan ini berubah menjadi sebuah pandangan keagamaan, kebudayaan, dan panduan moral yang dipersyaratkan untuk figurfigur keagamaan pada masa-masa selanjutnya hingga saat ini. Figur-figur ini adalah Kiyai, Penghulu Gading, Syaikh, Guru Tuan, dan Tuan Guru. ${ }^{25}$ Dengan kata lain, haji dalam hal ini tidak terbatas kepada tataran ibadah dan ritual keislaman semata, namun juga sebagai cara orang Sasak untuk memahami dan menjalani kehidupan itu sendiri. Karena alasan inilah, bukan hal yang aneh apabila naskah-naskah keagamaan yang menyebar di pedesaan orang-orang Sasak berorientasi kepada dua hal. Pertama, pembacaan hukum-hukum agama secara sufistik dan normatif yang terkait dengan simbolisasi Mekah, Ka'bah, dan Haji. Kedua, melalui naskah-naskah keagamaan dan pembacaaan berbasis tradisi tersebut, orang-orang Sasak secara langsung atau tidak mengaitkan perkembangan kebudayaannya dengan perkembangan sastra dan kebudayaan Melayu di Nusantara.

Pada tradisi Behikayat, pembacaan naskah-naskah kuno yang bertuliskan aksara Arab Melayu dan berisi ajaranajaran fikih dan tarekat menjadi media yang efektif untuk memberikan pemahaman yang tepat tentang hubungan antara fikih dan tarekat dalam kehidupan sehari-hari diantara masyarakat pedesaan.

Senada dengan fungsi sosial keagamaan dan kebudayaan kedua bentuk tradisi tersebut, tari Shaman di Lombok secara aktif mampu merubah pola pengajaran keagamaan dan zikir dalam Islam, dari Mushalla dan Masjid kepada penggunaan fungsi estetika dalam seni dan tari. Sehingga, dapat dikatakan bahwa Islam dan seni pada dasarnya bukan dua hal yang saling bertentangan.

Dengan melihat hubungan antara ketiga tradisi tersebut, yaitu Behaji, Behikavat, dan tari Shaman dalam membentuk hubungan yang cukup rumit antara pemaknaan kebudayaan dalam agama dan juga sebaliknya, maka pandangan-pandangan akan tradisi besar dan tradisi kecil saat memandang hubungan agama-budaya, -seperti yang dikemukakan oleh Clifford Geertzmenjadi tidak lagi ideal. ${ }^{26}$

\section{Perkembangan Fikih Lokal di Lombok: Dari Normativitas ke Ritual Hidup}

Apabila mengacu kepada hubungan sosial keagamaan antara Behaji, Behikayat, dan tari Shaman yang terkorelasi dengan naskah-naskah 
keagamaan, termasuk naskah-naskah tentang Mekah, pola anutan fikih orangorang Sasak terkait dengan nilai-nilai universal dalam kearifan-kearifan lokal orang Sasak. Kearifan ini diantaranya adalah tradisi Bebagi dalam Waris, tradisi Neteh dalam hukuman Zina, dan tradisi Behaji dalam Haji. ${ }^{27}$ Semua kearifan lokal ini mencerminkan bahwa tradisi dan keyakinan masyarakat Sasak adalah tradisi yang berdasarkan pada nilai-nilai Islam, khususnya fikih. Nilai-nilai tersebut berkaitan dengan konsep tauhid, akhlak, dan keadilan sosial. Melalui pengisahan kisah hidup dan perjuangan para nabi di seputar $\mathrm{Ka}$ 'bah misalnya, nilai-nilai tersebut diakulturasikan dengan tradisi lokal masyarakat Sasak oleh para mubalig yang menyebarkan Islam di Lombok. ${ }^{28}$

Pada wilayah sosio kultural, akulturasi ini terefleksi pada adat masyarakat Sasak yang sangat menekankan akhlak dan/atau sopan santun kepada Allah, sesama manusia, dan alam. Oleh masyarakat Sasak, hal ini disebut tate krame. ${ }^{29}$ Pada wilayah keagamaan, akulturasi ini menghasilkan praktek kesufian sekaligusmenjadikan ritual menunaikan ibadah haji sebagai pengukuh praktek kesufian mereka, dan simbolisasi $\mathrm{Ka}$ 'bah atas prosesi realisasi nilai-nilai yang dikandung ibadah haji dalam kehidupan. Oleh masyarakat Sasak, prosesi ini disebut dengan ritual behaji. $^{3 n}$ Melalui ritual behaji, masyarakat Sasak berlomba-lomba mengaplikasikan nilai-nilai kesalehan yang terkandung di dalam ibadah haji, baik berupa kesalehan individu maupun kesalehan sosial.

Terkait dengan hal-hal tersebut, ritual yang hingga saat ini menjadi saksi sejarah hubungan naskah-naskah keagamaan tentang Mekah dengan konstruksi dan sekaligus rekonstruksi pola anutan keagamaan dan kebudayaan orang-orang Sasak adalah ritual Behaji dan Behikayat. Di antara orang-orang Sasak, kedua ritual ini menyokong pribumisasi ajaran-ajaran fikih pada kearifan-kearifan lokal yang dianut olah orang-orang Sasak, seperti keadilan dalam waris, hukuman bagi pelaku zina, dan pelarangan perusakan alam beserta isinya. Dalam hal ini, keadilan dalam waris ditandai dengan tradisi pemberian hibah bagi ahli waris perempuan yang kurang mampu dan mendapatkan bagian waris yang lebih sedikit. Lalu lebih dipilihnya hukuman isolasi dari sebuah desa bagi pelaku zina dari hukuman rajam. Dan ritual menjaga alam sebagai bagian dari manifestasi makna-makna keagamaan dalam haji. ${ }^{31}$

Selain ditandai dengan pribumisasi ajaran-ajaran fikih dalam tataran sosial, signifikansi peran penting naskah-naskah tentang Mekah pada wilayah sosio kultural ditandai juga dengan perubahan mekanisme sosio kultural yang ditandai dengan perubahan simbol puncak spiritualitas diantara orang Sasak, yaitu dari Gunung Rinjani ke Ka'bah di Mekah. Perubahan simbol spiritual ini yang tentunya menceritakan Mekah dengan Ka'bahnya dapat dilihat pada pengajaran makna-makna tauhid dan ajaran-ajaran sosial dalam Islam pada naskah Serat Rengganis dan Manusia Jati. $^{32}$ Sehingga, dapat dikatakan dalam hal ini bahwa kulturisasi isi naskahnaskah keagamaan melibatkan pemaknaan keagamaan pada elemenelemen kebudayaan yang lain, seperti ritual dan simbol.

Berkaitan dengan peran ritual dan simbol tersebut, Joachim Wach melihat bahwa agama memiliki tiga bentuk dalam pengungkapan nilai universalnya, yakni (1) belief system, (2) system of worship, dan (3) system of social relation. Pengungkapan nilai-nilai universal ini merupakan inti dari nilai religiusitas. Dalam tataran nilai, religiusitas agama memiliki lima dimensi, yakni dimensi kepercayaan (belief); dimensi praktek (practice); dimensi perasaan (feeling); dimensi pengetahuan (knowledge); dimensi efek (effect). ${ }^{74}$ Semua saling 
berkaitan, membentuk stigma masyarakat tentang doktrin keagamaan dan kultur dalam sebuah kebudayaan.

Dalam kehidupan keberagamaan sendiri, Geertz melihat agama sebagai pola dari tindakan (pattern of behavior), yaitu agama berfungsi sebagai pedoman yang dijadikan kerangka interpretasi manusia. Selain itu, agama juga merupakan pola dari tindakan, yaitu suatu hal yang hidup dalam diri manusia dan berpengaruh dalam kehidupan seharihari. Karena fungsinya ini, agama dianggap Geertz sebagai bagian dari sistem kebudayaan. ${ }^{35}$ 'Pola-bagitindakan' terkait dengan sistem nilai atau sistem evaluatif, sedangkan 'pola-daritindakan' terkait dengan sistem kognitif atau sistem pengetahuan manusia. Hubungan antara pola-bagi-tindakan dan pola-dari-tindakan tersebut terletak pada sistem simbol yang memungkinkan pemaknaan dilakukan. ${ }^{36}$

Dengan memberi contoh berupa upacara keagamaan yang dilakukan oleh suatu masyarakat sebagai pola-daritindakan, sedangkan ajaran yang diyakini kebenarannya sebagai dasar atau acuan melakukan upacara keagamaan sebagai pola-bagi-tindakan, Geertz memperkuat pandangannya mengenai kebudayaan sebagai sesuatu yang memiliki dua elemen, yaitu sebagai sistem kognitif, sistem makna, dan kebudayaan sebagai sistem nilai. ${ }^{37}$ Baik sistem kognitif, sistem makna, ataupun sistem nilai, semua terletak pada sistem simbol yang memungkinkan lahirnya pemaknaan atau interpretasi. Inilah yang menyebabkan ada perbedaan sistem kepercayaan, nilai, dan upacara pada tiap varian keagamaan. ${ }^{38}$ Adanya perbedaan tampak pada variasi identitas muslim Jawa di Mojokuto yang diteliti oleh Geertz. Dengan melihat pelaksanaan ritual slametan di kalangan masyarakat Abangan, para Santri yang taat dalam pelaksanaan ajaran-ajaran Islam. dan kelompok priyayi yang merupakan keturunan ningrat dan pegawai pemerintahan, Geertz menggolongkan praktek keagamaan masyarakat Islam di Mojokuto menjadi Abangan, Santri, dan Priyayi. ${ }^{39}$

Terkait pandangan Geertz mengenai sistem simbol dan fungsi ritual tersebut, maka runutan kulturisasi naskah-naskah tentang Mekah melalui tradisi Behaji dan Behikayat secara historis maupun sosial kebudayaan memperkuat pandangan Geertz tentang sistem simbol sebagai perantara di antara sistem kognitif dan sistem nilai dalam menghasilkan sistem makna pada sebuah agama. ${ }^{40}$ Sehingga ritual keagamaan ini merupakan suatu bentuk upacara berisi simbol-simbol yang menimbulkan pengalaman yang suci. Victor Turner, dalam hal ini menganalisis hakikat dan karakter spiritual dari sebuah tradisi sebagai sesuatu yang mendorong penyederhanan struktur sosial masyarakat. Dapat dilihat dari penekanan akan hubungan-hubungan yang bersifat umum, bukan partikularistik dalam sebuah tradisi. ${ }^{41}$

Sebagai sebuat tradisi, hakikatnya, Behaji dan Behikayat merefresentasikan signifikansi kesusastraan dan maknamakna universal ajaran-ajaran syari'ah dalam naskah-naskah keagamaan terhadap tumbuh kembangnya fikih lokal yang mentradisi dan membumi. Baik itu yang terkait dengan simbolisasi perjuangan tiga nabi di Mekah yaitu Adam, Ibrahim, dan Muhammad saat menegakkan ajaran tauhid dan keadilan sosial dalam ritual Behaji ${ }^{42}$, maupun dengan kulturisasi ajaran-ajaran fikih dalam tradisi Behikayat. Sehingga, dalam hal ini, kontekstualisasi ajaran-ajaran fikih dalam Islam, dan juga maknamakna universal dalam kebudayaan pada ranah sosio kultural adalah sebuah kemestian dari agama beserta budaya itu sendiri.

Selain itu, melihat fakta menarik di atas yang mengaitkan Mekah, Ka'bah, dan haji dalam tradisi Behaji dan Behikayat sebagai cara melakukan 
pribumisasi ajaran-ajaran fikih dalam Islam dengan pola-pola kulturisasi isi naskah-naskah keagamaan mengenai Mekah mencerminkan bahwa naskahnaskah keagamaan tidak sekedar sebuah tulisan-tulisan yang berasal dari masa lalu. Namun, lebih dari itu, naskahnaskah keagamaan adalah sebuah kebudayaan yang hidup. Begitupun dengan peran fikih yang tidak berkarakter normatif. Namun juga memiliki karakter sosial dan bahkan karakter kebudayaan yang kental.

\section{Penutup}

$\begin{array}{ccc}\text { Sebagai } & \text { bagian penting } & \text { dari } \\ \text { perkembangan } & \text { keagamaan } & \text { dan }\end{array}$

\section{Catatan Akhir:}

I Mengenai penjelasan perkembangan bahasa Melayu Loloan Bali, lihat I Nyoman Suparwa, " $N$ komodasi Bahasa Loloan Bali dalam Dinamika Masyarakat Kultural: Kajian Adaptasi Fonologi dari bahasa Lingkungantnya", dalam Jumal Dinamika Kebudayaan, Vol. XI No. 1, 2009.

"J.T. Collins, Khazanah Dialek Melayz, cet. 1 (Bangi: University Kebangsaan Malaysia, 1996), hlm. 13-4.

"Rimbu adalah pakaian tradisional wanita Bima yang bentuknya seperti Hijab orang Arab. Selain berfungsi sebagai penutup aurat, Rinbu juga adalah penanda identitas kebudayaan orang Bima.

${ }^{4}$ Pola pengisahan dalam Hikayat Orang Melayı yang dimaksud tidak hanya mengenai cerita yang berkembang didalam masyarakat dan cerita kehidupan istana, namun juga tentang makna-makna kehidupan itu sendiri.

"Lihat Azyumardi Azra, Jaringan Llana Timur Tengah dan Kepulauan Nusantara Abad XVII \& XVII (Jakarta: Kencana, 2007), III:1202

${ }^{5}$ Seringkali berbagai naskah keagamann terkait secara mendalam dengan perkembangan tradisi dan kultur masyarakat. Mengenai hal ini, lihat Suripan Sadi Hutomo, Filologi Lisan (Jakarta: CV Lautan Rezeki, 1999), I: 6. Selain itu, lihat juga Nyoman Kutha Ratna, Teori, Metode, dan Tekmik Penelitian Sastra, Cet.1 (Yogyakarta: Pustaka Pelajar, 2008) kebudayaan yang berbasis sastra, pembentukan fikih lokal yang berbasis naskah-naskah atau manuskripmanuskrip keagamaan di Lombok menjadi bukti penting peran signifikan kesusastraan dalam manuskrip terhadap akulturasi ajaran-ajaran normatif dalam agama dengan makna-makna kebudayaan dalam tradisi-tradisi lokal di Nusantara. Selain itu, tradisi ini dengan berbagai ritual dan tradisi yang mengikutinya, seperti tradisi Behikayat dan Bewacan juga membuktikan fikih sebagai tradisi yang hidup dan berkembang, bukan sekedar ajaran keagamaan yang statis dan dogmatis.

${ }^{7}$ Maknta-makna ini diantaranya adalah keadilan sosial dalam hukuman bagi pezina dan aturan hibah saat membagi harta warisan bagi yang tidak mampu.

${ }^{8}$ Mengenai latar belakang historis aksara Kawi dan Jawi, lihat Baroroh Baried, Pengantar Teori Filologi (Yogyakarta: Fakultas Sastra UGM, 1994), II: 25

"Lihat Martin van Bruinessen, "Mencari Ilmu dan Pahala di Tanah Suci," dalam Jurnal Ulumul Qur'an No. 5, hlm. 43-4

${ }^{10}$ Lihat Lalu Muhammad Ariadi, Haji Sasak: Sebuah Potret Dialekika Haji dengan Kebudaraan Lokal (Jakarta: Impressa, 2012), I: 9

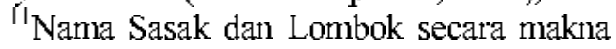
dan filosofis terkait baik dengan tradisi dan kebudayaan masyarakat Sasak. Dalam masyarakat Sasak, Sasak berarti bambu-bambu ysang dijadikan satu dan menjadi sebuah rakit yang kokoh dan Lombok berarti lurus dan konsisten. Lihat Lalu Muhammad Azhar, Sejarah Daerah Lombok: Ana Banjar Getas (Mataram: Yaspen Pariwisata Pejangeiq, 1997), I: 21. Lihat juga Lalu Lukmant, Lombok (Mataram: Pokja, 2004), I: 1. Setelah datangnya Islam di Lombok, pemaknaan Sasak disepadankatı dengan Yang Satu atau Esa dan Lombok dengan konsep Isticamah dalam Islam.

${ }^{13}$ Badan Pusat Statistik Prop. NTB, NTB Dalam Angka 2005 (Mataram: UD. Fajar Indah, 2005), hlm. 4.

${ }^{\text {I3 }}$ Total penduduk NTB adalah sekitar 2.600 .000 ribu jiwa dengan hunian terbesar di Pulau Lombok, yaitu 2.100.000 ribu jiwa. Lihat Badan Pusat Statistik Prop. NTB, hlm. 6. Pemeluk Islam di Propinsi ini mayoritas adalah orang Sasak. Karena Islam sebagai sebuah agama yang dianut oleh keseluruhan orang Sasak, maka 
muncul sebuah istilah yang menutujukkan identitas keislaman orang Sasak, yaitu "dengan Sasak no dengan Islam" atau orang Sasak adalah orang Islam. Lihat Djalaludd in Arzaki dkk, Niaimilai Agama dan Kearifan Budana Lokal Siku Bangsa Sasak Dalam Phralisme Kehidwan Benmasyarakat: Sebuah Kajian AntropologisSosiologis-Agamis, Cet. 1 (Mataram: Pokja Redam NTB-Indonesia, 2001).

${ }^{14}$ Departemen Pendidikan dan Kebudayaan, Sejarah Daerah Nasa Tenggara Barat, (ttp., Proyek Kajian Kebudayaan Daerah, 1977/1978), hlm. 1-2. Dalam Kitab Negarakentagama, kedua istilah ini disebutkan sebagai pembeda wilayah antara Lombok bagian Barat (Lombok Mirah) dengan bagian Timur (Sasak $A d$ ). Di dalam kitab ini juga disebutkatn bahwa pada pertengahan abad ke-14 setelah wilayah kerajaan Bali, terdapat beberapa kerajaan yaitu: Bima, Dompu, Taliwang, Seran, dan Utan Kedali di Pulau Sumbawa dan Sasak di Lombok.

${ }^{15}$ Suditman, Gumi Sasak dalam Sejarah (Pringgabaya: KSU Prima Guti, 2007), I: 3-4. Oleh Alfred Russel Wallace, orang Lombok diindikasikan lebih spesifik sebagai ras Melayu. Lihat Alfred Russel Wallace, Kepulawan Musanara: Sebuah Kisah Perjalanan, Kajian Mamsia, dan Alam, terj. Tim Komunitas Bambu (Depok: Komunitas Bambu, 2009), I: 109-10.

${ }^{16}$ Selain mengindikasikan adanya kebudayaan yang sama, temuatn ini menuniukkan bahwa sejak zamat perunggu telah terjadi hubungan dagang antara masyarakat yang tinggal di Lombok dengan masyarakat yang tingoal di luar Lombok. Ibid, hlm. 3-4.

${ }^{17}$ Selaitı menjadi bagian penting dari tradisi Pentuskahan yang berkembang di Lombok, Behikanat dan Bewacan juga metupakan ritual yang terkait dengan daur hidup orang Sasak. Ini terlihat pada kebiasaan orang Sasak mengadakan salah satu dari ritual ini pada berbagai acara orang desa, baik pada perayaan kelahiran bayi, pernikahan, maupun perayaan panetı.

${ }^{18}$ Departemen Pendidikan dan Kebudayaan, Direktorat Jenderal Kebudayaan, Museum Negeri NTB, Bunga Rampai Kuipan Naskah Lama dan Aspek Pengetahnamma (Mataram: Museum Negeri NTB, 1991), I: 37, 71.

${ }^{14} \mathrm{Bagi}$ para pendengatnya yang pertiah mendengar suara Serunai, seritigkali mereka menganggap suara Pereret seperti sama dengan suara Serunai. Wawancara dengan Djalil, seorang peniup Pereret.

${ }^{3}$ Untuk pengetahuan awal mengenai naskah ini, lihat Mujib dan Achmad Cholid Sodrie, Khazanah Naskah Desa Ketangga Kecamatan Suela, Kabupaten Lombok Tim, cet.
1 (Jakarta: Kementerian Kebudayaan dan Pariwisata, 2004).

${ }^{2}$ Mengenai latar belakang historis aksara Kawi dan Jawi, lihat Baroroh Baried, Penganar Teori Filologi (Yogyakarta: Fakultas Sastra UGM, 1994), I: 25.

Mengenai dokumentasi sebagian naskah-traskah yang beraksara $\mathrm{Arab}$ Melayu, lihat Mujib dan Achmad Cholid Sodrie, Khazanah Naskah Desa Ketangga, Kecamatan Suela, Kabupaten Lombok Tim, Cet. 1 (Jakarta, Kementerian Kebudayaan dan Pariwisata, 2004).

"Lihat Aswandikara, Konsep Tasawn Naskah Indarjaya Sasak (Mataram: Arga Puji Press, 2007), I: 373-78.

${ }^{3}$ Lihat Departemen Pendidikan dan Kebudayaan, Sejarah Daerah Nasa Tenggara Barat, hlm. 15-26.

${ }^{35}$ Tentang penjelasan Tuan Guru dan figur keagamaan yang laitı di Lombok, lihat Jamaludditr. Pensepsi dan Sikap Masyarakat Sasak terhadap Tuan Gunt. (Yogyakarta: CRCSSekolah Pascasarjana UGM, 2007), hlm. 45-56.

"Lihat Clifford Geettz, The Religion of Java (New York: The Free Press of Glencor, 1960).

${ }^{T}$ Semua tradisi terkait etat dengan ajaranajaran fikih dalam Naskah, seperti keterkaitan tradisi Behaji dengan naskah Sabuk Desa Ketangga.

${ }^{3}$ Berdasarkan berbagai cerita rakyat yang berkembang di Lombok dan ajaran-ajaran keagaman yang tertulis di berbagai naskah, seperti dalamn naskah $\mathrm{Atna}$ Kidung dan $K a b a h a /-$ Hagigah al-Marifah, pengajaran yang paling dominatn diceritakan adalah berbagai pengajaran yang ada di dalam cerita nabi, khusustrya yang hidup di sekitar Ka bah. Hal ini metrjadi domitnatn karena Islam yang masuk dan berkembang di Lombok pada masa-masa awal adalah Islam Sufistik.

Tate Krame adalah sebuah konsep adat yang sangat menekankat praktek sopan dan santun saat menyembah Allah SWT, menghadapi manusia dan alam. Konsep ini serupa dengan ajaran akhak al-kanimah dalam Islam. Lihat Lalu Lukmat, Lombok (Mataram, Pokja:2004), I: 10.

${ }^{30}$ Ritual behaji adalah ritual yang dilakukan masyarakat Sasak saat berhaji datı setelah berhaji. Sebelum berangkat haji, seorang Muslim pada masyarakat Sasak akan melakukan silaturahmi dengan masyarakat, berdoa bersama para pemuka agama, dan ziarah ke makam, utamanya orang yang disucikan. Setelah pulang dari metnunaikan haji, seorang haji akan menahan dirinya dari hawa nafsu, termasuk bersenggama dengan istrinya selama 40 hari. Saat ini, ritual ini 
hanya dilakukan oleh penganut tarekat di Lombok.

${ }^{3}$ Keadilan dalam waris melalui hibah dikenal dengan $B e b a g i$, isolasi bagi pelaku zitra dikenal dengan Neteh, dan penjagaan alam terkumpul dalam falsafah mentok, memiok, dan merananak, yang dikenal dengan Metu Telu atau Weat Ted.

7 Mengenai penjelasan awal dari Serat Rengganis dan Manusia Jati, lihat data-data naskah yang dikumpulkan para peneliti dari Museum NTB dalam Departemen Pendidikan dan Kebudayaan. Bunga Rampai Kuipan Naskah Lama dan Aspek Pengetahmanma, Cet. 1, (ttp., Proyek Kajian Kebudayaan Daerah, 1990).

${ }^{31}$ Joachim Wach, Sociology of Religion (Chicago: The University of Chicago Press, 1948), hlm. 37 .

${ }^{34}$ Roland Robertson, (ed.), Agama Dalam Analisa dan Intepretasi Sosiologis, terj. Achmad Fedyani Saifuddin (Jakarta: CV Rajawali, 1992), I: 295-97.

${ }^{35}$ Lihat Clifford Geertz, "Religion as Cultural System," dalam Michael Banton, Anthropological Approaches to the Sudy of Religion, 5. Penyataan Geertz mengenai agama sebagai bagian dari kebudayaan adalah senada dengan pendapat A.R. Radcliffe Browti yang berpendapat bahwa agama sebagai unsur kebudayaan yang dianggap sebagai bagian dari struktur sosial yang diperlukat bagi solidaritas datn ittegrasi. A.R. Radcliffe Browt1, Stmktu dan Fungsi dalan Masyarakat Prinitif (Kualalumpur: Dewan Bahasa dan Pustaka Kementerian Pelajar Malaysia, 1980), I: 204.

${ }^{31}$ Dalam kerangka pemikiran ini, Geettz memosisikan diri dengan melihat kenyataan dari sudut pandang pelaku. Lihat Clifford Geertz, Local Knowledge (New York: Basic Books Inc, 1983), I: 55.

${ }^{37} \mathrm{Hal}$ ini terkait dengan pandangan bahwa kebudayaan adalah pedoman bagi kehidupan masyarakat yang diyakini kebenarantnya oleh masyarakat tersebut. Lihat Parsudi Suparlan, "Penelitian Agama Islam: Tinjaunan Disiplin Antropologi", Dalam Mastuhu dan Dedetı Ridwatn, Tradisi Bant Penelitan Agana Islam Tinjauan Anar Disiplin Hhm (Jakarta: Pusjarlit, 1998), [: 111.

${ }^{38}$ Clifford Geertz mengatakan bahwa kebudayaan pada intinya terdiri dari tiga hal, yaitu sistem pengetahuan atau kognitif, sistem nilai, dan sistem simbol. Lihat Ignaz Kleden, "Dari Ethografi ke Etnografi tentang Etnografi: Antropologi Clifford Geettz dalam Tiga Tahap", dalam Clifford Geertz, After The Fact: Dua Negen Empat Dasawarsa Satu Antropolog (Yogyakarta: LKiS, 1999), I: X\%.
3*Pada masyarakat Abangan, Slametam merupakan ritual terpenting masyarakat $A$ bangan yang bertujuan untuk menenangkan roh-roh dan memperoleh keadaaan slanet. Sedangkatı pelaksanaan ritual Slametan dikalangan para Santri dan Privay telah mengalami perubahan dengan masuknya doa-doa dan zikir dari Islam. Lihat Clifford Geettz, The Religion of Java, hlm. 5-15. Penelitiannya tersebut didasarkan kepada pandangan masyarakat Mojokuto mengenai kepercayaan, keyakinan keagamaan, ritus keagamaan, dan ideologi politik. Thomas O'Dea, Sosiologi Agana: Suatu Pengenalan Awal, terj. Yasogama (Jakarta: PT Raja Grafindo Persada, 1995), I: 35-36.

${ }^{40}$ Nur $\quad$ Syam, Madzhab-Madzhab Antropologi (Surabaya: LKiS, 2007), I: 91-92.

${ }^{41}$ Lihat Victor Turtner, "Pilgrimage as Social Process", dalam Dranas, Ficlds and Metaphors: Swmbolic Action in Hhman Socien (Itacha, New York: Cornell University Press, 1974), I: 95-96. Pernyataan Turtner mengenai penyederhanaan struktur sosial tersebut dapat dilihat pada struktur sosial masyarakat yang tidak lagi mengacu pada perbedaan status, namun mengacu pada egaliterianisme di dalam masyarakat.

${ }^{43}$ Di Mekah terdapat Ka'bah yang dikenal sebagai rumah pertama yang dibangun $\mathrm{Nllah}$ sebagai barakah dan petunjuk bagi manusia serta merupakat tempat ibadah paling tua di Timur Tengah. Ka'bah dibangun oleh Ibrāhīm-kakek para nabi bersama putranya Ismāîl. Lihat Muhammad Jawwād Mughniyah, Fikih Lima Mazhab, ter, Afif Muhammad (Jakarta: PT Lentera Bastitama, 1999), I: 302. Haji diwajibkatn bagi umat Islam yang mampu [istifá 'ah). Empat mazhab (Malikī, Hanafī, Shäfi'ī dan Hanbalī) menafsitkan mampu (isfifá $a h$ ) tidak hanya dengan mampu secara materi dan nonnateri, namun mampu dalam arti nafkah untuk orang yang wajib diberikan nafkah selama seseorang menumaikan ibadah haji, yang wajib untuk dipenuhi. Lihat ' $\mathrm{Abd}$ al-Rahman al-Jazì'1, Fikih Empat Mazhab, terj. Moh. Zuhri (Semarang: CV Asy-Syifa, 1993), I: 535.

\section{DAFTAR PUSTAKA}

Agus, Bustanudin. Agama dalam Kehidupan Manusia: Pengantar Antropologi Agama. Jakarta: PT RajaGrafindo Persada, 2006.

Ariadi, Lalu Muhammad. Haji Sasak: Sebuah Potret Dialektika Haji 
dengan Kebudayaan Lokal.

Jakarta: Impressa, 2012.

Aswandikari. Konsep Tasawul Naskah Indarjaya Sasak. Mataram: Arga Puji Press, 2007.

Azra, Azyumardi. Jaringan Ulama Timur Tengah dan Kepulauan Nusantara Abad XVII \& XVIII. Jakarta: Kencana, 2005.

Baried, Baroroh. Pengantar Teori Filologi. Yogyakarta: Fakultas Sastra UGM, 1994.

Bruinessen, Martin Van. Kitab Kuning: Pesantren dan Tarekat. Bandung: Mizan, 1999.

Departemen Pendidikan dan Kebudayaan. Bunga Rampai Kutipan Naskah Lama dan Aspek Pengetahuannya. Ttp.: Proyek Kajian Kebudayaan Daerah, 1990. Sejarah Daerah Nusa Tenggara Barat. Departemen Pendidikan dan Kebudayaan, Pusat Penelitian Sejarah dan Budaya Proyek Penelitian dan Pencatatan Kebudayaan Daerah, 1977/1978.

Dhofier, Zamahkhsyari. Tradisi Pesantren; Studi tentang Pandangan Hidup Kyai. Jakarta: LP3ES, 1982.

Fathurrahman, Oman. Tarekat Syattariyah di Minangkabau. Jakarta: Pusat Pengkajian Islam dan Masyarakat (PPIM) UIN Jakarta, KITLV, 2008.

Geertz, Clifford. After The Fact: Dua Negeri Empat Dasawarsa Satu Antropolog. Yogyakarta: LKiS, 1999.

Kebudayaan dan Agama, terj. Francisco Budiman Hardiman. Yogyakarta: Kanisius, 1992. Local Knowledge. New York: Basic Books Inc, 1983.

. The Religion of Java. New York: The Free Press of Glencoe, 1960.
Hutomo, Suripan Sadi. Filologi Lisan. Jakarta: CV Lautan Rezeki, 1999.

Jamaluddin. Persepsi dan Sikap Masyarakat Sasak terhadap Tuan Gum. Yogyakarta: CRCSSekolah Pascasarjana UGM, 2007.

"Sejarah Sosial Islam di Lombok Tahun 1740-1935", disertasi tidak diterbitkan, Jakarta: 2010.

Al-Jazīrī, 'Abd al-Rahman. Fikih Empat Mazhab, terj. Moh. Zuhri. Semarang: CV. Asy-Syifa, 1993.

Mughniyah, Muhammad Jawwād, Fikih Lima Mazhab, ter. Afif Muhammad. Jakarta: PT Lentera Basritama, 1999.

Mujib dan Achmad Cholid Sodrie. Khazanah Naskah Desa Ketangga, Kecamatan Sula, Kabupaten Lombok Timur. Jakarta: Kementerian Kebudayaan dan Pariwisata, 2004.

Putuhena, M. Shaleh. Historiografi Haji Indonesia. Yogyakarta: LKIS, 2007.

Ratna, Nyoman Kutha. Teori, Metode, dan Teknik Penelitian Sastra. Yogyakarta: Pustaka Pelajar, 2008.

Syam, Nur. Madzhab-Madzhab Antropologi. Yogyakarta: LKiS, 2007.

Sudirman. Gumi Sasak dalam Sejarah. Pringgabaya: Yayasan Budaya Lestari bekerjasama dengan KSU Prima Guna, 2007.

Turner, Victor. "Pilgrimage as Social Process", dalam Dramas, Fields and Metaphors: Symbolic Action in Human Society. New York: Cornell University Press, 1974. 